\title{
Yield development of flax varieties and lines within variable environment in Latvia
}

\author{
Inga Stafecka ${ }^{1}$, Veneranda Stramkale ${ }^{1}$, Dace Grauda ${ }^{2}$ \\ ${ }^{1}$ Agricultural Science Centre of Latgale, Kultūras sq. 1, Vil̄āni, Vil̄ānu distr., Latvia Ph.: \\ +37129465044,e-mail:strzin@apollo.lv \\ ${ }^{2}$ Institute of Biology, University of Latvia, Miera Street 3, Salaspils, Latvia; ph.: +371 \\ 67945435,e-mail: andra@email.lubi.edu.lv; dace@email.lubi.edu.lv; \\ izaks@email.lubi.edu.lv
}

\begin{abstract}
Flax is the multiple purpose crop cultivated in temperate region. Seeds of oil flax recently became important constituent for many industrial applications, such as pharmacy, medicine, food production etc. and have high prospective for use in Latvia. Understanding the underlying processes that limit seed yield in flax is major with respect to enhancing the breeding of flax for yield improvements. The aim of study was evaluated 29 flax varieties and lines (including 20 Latvian origins) plasticity of seed yield production in changeable environmental conditions. The experiment was carried out in the Agricultural Scientific Centre of Latgale on field trials over the period 2010-2013. According to 4 years results was to establish the nature of relation between seed yield and hydrothermal coefficient (HTC), and seed yield and another yield components of flax. Apart from the changing conditions highest seed yield were produced from a varieties 'Lirina' $\left(2.54 \mathrm{~h}^{-1} \mathrm{t}\right)$, high seed oil content from variety 'Amon' (53.03\%). Positive and significant relationships were found between seed yield and HTC 'T30-28-6-94'( $r=+0.98 *)$, 'German Serenade' $\left(r=+0.95^{*}\right)$ and 'Scorpion' $(r=+0.95 *)$.
\end{abstract}

Keywords: flax, genetic resource, seed yield.

\section{INTRODUCTION}

Flax (Linum usitatissimum L.) is a good example of a multiple purpose crop being utilized for oil and fiber. It was one of the eight "founder crops" of agriculture, was a principal source of oil and fiber from prehistoric times until the early 20th century, and still remains a crop of consider able economic importance [1], [2].

The seed of flax (i.e. linseed) produces oil that is rich in unsaturated fatty acids, especially a-linolenic acid (C18:3), polymers of which are used in linoleum, paints and other finishes. Consumption of the oil or seed has been reported to have beneficial effects on cardiovascular health and in the treatment of certain cancers and inflammatory diseases [3]. Health benefits are derived from both the a-linolenic acid, rich supply of soluble dietary fiberand and other components of the seed, including lignans such as secoisolariciresinol diglucoside (SDG), which is an antioxidant and the precursor of several phytoestrogens [4], [5]. Flax seed is also used in animal feed to increase levels of alinolenic acid in meat or eggs [6]. A $100 \mathrm{~g}$ portion of flaxseed provide $1890 \mathrm{~kJ}$ and $450 \mathrm{kcal}$ energy and contains approximately about $41 \%$ oil, $20 \%$ protein, $8 \%$ moisture, $4 \%$ ash and $27 \%$ total dietary fiber.
Also, flaxseed is known to be nature's best source of omega-3 oil [7].

In recent years, the food and pharmaceutical industries have paid attention to the properties of flax mucilage. Due to its specific biological activities, seed mucilage (SM) can be used as a thickening agent [8], as a substitute to chemical additives for food preservation [9] and as an excipient in drug formulations [10]. In contrast to the human food industry, the animal feed sector requires flax cultivars with low mucilage content to prevent negative effects on animals' digestion [11].

Yield is a quantitative characters and it is influenced by both genetics and environmental condition [12]. As environmental factors exert a major role in determining yield potential it is important to understand environmental effects on yield. Weather patterns and soil types affect seed yield in flax, but plant density has little effect because flax compensates for reduced stand densities mainly through increasing the number of boils per plant [13]. Temperature affects the rate of crop development however; excessively high temperatures during flowering limit flax seed production due to reduced seed set and boil numbers [14]. 
Crop yield is a polygenic trait that is greatly affected by environment and gene-environment interactions. Yield related genes are affected to a different degree by environment in any given year; therefore, selection based on yield per se is not always effective in the long term [15]. Indirect selection through yield components is likely to be more effective than focusing on grain yield (a trait generally knows to be highly influenced by the environment with low heritability) because the components of yield are less environmentally sensitive and have higher heritability [16], [17]. Taking in account the facultative cross-pollination, the development of genetically stabile lines could take more than 15 years [18], [19].

Yield is the most important and complex trait in crops that shows correlations with other traits [20]. In linseed, yield and its components such as 1000 seed weight (TSW), seeds per boll (SPB), and bolls per area (BPA), are quantitatively inherited and controlled by many genes affected by multiple interactions with other genes and the environment [21]-[23]. An understanding of impact of environmental influence on yield-related traits is of practical value to breeders because such information assists in the design of efficient breeding strategies and for farmers in the choice of variety for cultivation.

Accordingly the aim of this study was evaluated plasticity of seed yield production in changeable environmental conditions for 29 flax varieties and lines (including 20 Latvian origins).

\section{MATERIALS AND METHODS}

\section{Field experiments}

This study was carried in four consecutive growing seasons $(2010$ - 2013) out at the field trial in the Agricultural Science Centre of Latgale in Latvia. Experimental material for the present study consisted of 29 flax varieties and lines (including 20 Latvian origins) [24]. Flax varieties and lines were compared with the standard varieties 'Lirina' and 'Vega 2'.

\section{Evaluated flax varieties and lines}

- 'Lirina', 'Scorpion', 'German Serenade' (Germany origin varieties).

- 'Bildstar', 'Amon' (Czech Republic origin varieties).

- 'Princess', 'Duchess' (France origin varieties). 'Flanders' (Canada origin varieties).

- 'ST Vega2' (Lithuania origin variety).

- 'TVR 03', 'T VR02', 'T 36-26/4-8-94', 'T 31-42-94', 'T 30-28-6-94', 'K 47-17/11-195', 'T 30-15/4-3-94', 'K 30-14/14-18-94', 'K 30-14/14-11-94', 'T 29-14/4-2-94', '38', '37-50', '37-49', '37-34', '37-28', '37-10/1',
'37-9/1', ‘37-5', ‘37-2', ‘37-1' (Latvia origin lines).

Seed yield and 1000 seed weight was determined in each harvested parcel area. Number of seed-vessel per plant and seed number per seed-vessel were determined by randomly selected 10 plants in each parcel. Oil content of each variety and line was determined by grain quality analyzer "Infratec 1241". Each variety and line was noted the vegetation period.

Agrochemical properties of the soil were determined four experimental years.

\section{Meteorological conditions}

Agro-meteorological conditions determined by ADCON installed meteorological stations which are connected to the computer program Dacom Plant Plus. Facility provides information in direct nearby field trials.

This study was calculated hydrothermal coefficient (HTC) of each month during the growing season (are presented on Fig. 1). Hydrothermal coefficient has been calculated by applying formula (1) of G.Selyaninov [25]:

$$
\mathrm{HTC}=\Sigma \times / \Sigma \mathrm{t} \times 10
$$

where $\Sigma \mathrm{x}$ and $\Sigma \mathrm{t}$-accordingly sum of precipitations and temperatures in the period, when the temperature has not been lower than $10^{\circ} \mathrm{C}$.

Criteria:

HTC $\leq 0.5$ - strong, very strong drought;

HTC $=0.6-$ weak drought;

HTC $\leq 0.7-$ dry conditions;

HTC $\geq 1.0-$ characterizes the sufficient moistening.

\section{Data analysis}

Microsoft Excel program was used for data statistical processing. Used data analysis tools Descriptive Statistics and Correlation tests. This study was carried out to determine the effect of significant and not significant relationship between seed yield and yield components, and between seed yield and HTC.

\section{RESULTS AND DISCUSSION}

Weather conditions in 2010 - 2013 seasons of vegetation periods were different and varied impact on flax growth and development. Basically during the growing season of flax lasts from May to the end of August.

During the 2010 in the first period of flax growing seasons were characterized by the sufficient moistening HTC range from 1.12 to 1.64 and second period with strong, very strong drought HTC range from 0.34 to 0.37 . The weather conditions for flax in the vegetation period have been favorable for the flax yield development because from "fir-tree" stages to flowering stages are wet and in maturation stage of the 
hot, dry weather [26]. The year 2011 is characterized as the driest year HTC range from 0.42 to 0.84 only in May was sufficient moistening HTC was 1.11. And year 2012 characterized by the highest moisture content HTC ranged from 1.73 to 2.86. During the 2013 at the beginning of the season is a very large amount of moisture in April, HTC was 4.75. Excess moisture content adversely affects the germination of flax in May. Throughout the growing season HTC is characterized the sufficient moistening range from 0.92 to 1.27 , except June with weak drought, HTC was 0.56 .

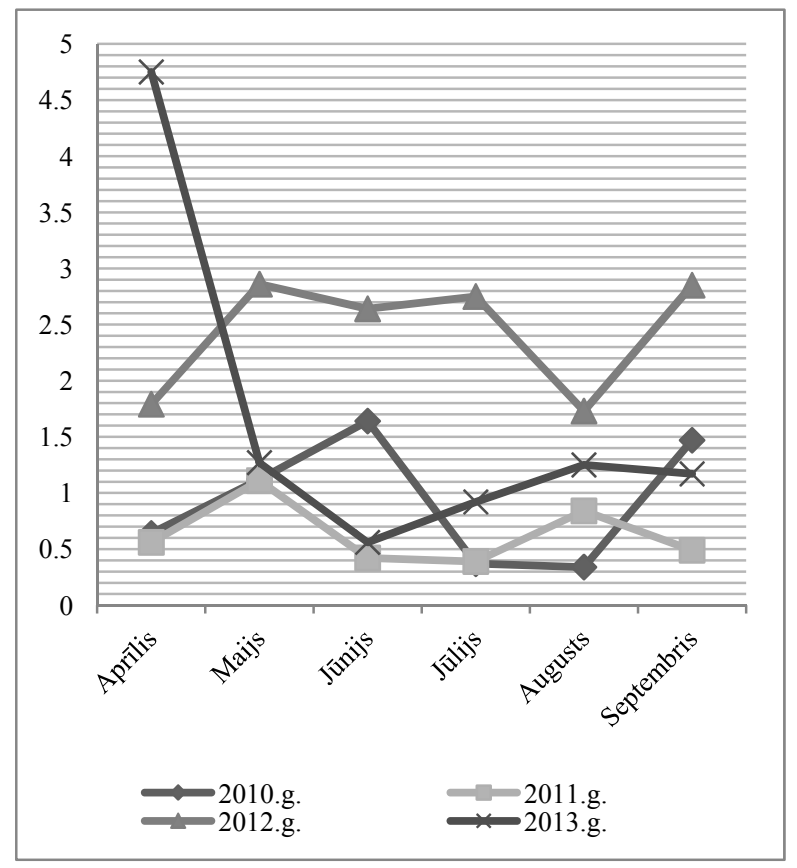

Fig.1. Comparison HTC in 2010-2013 growing seasons of flax

Fertilization and agrochemical actions for all flax varieties and lines was equivalent. Soil agrochemical characteristics of the four experimental years were not significantly different: organic matter content of the soil is $6.5 \%, \mathrm{pH}-6.4$ to 7.0 , phosphorus contents $\mathrm{P}_{2} 0_{5}$ - 130 to $145 \mathrm{mg} \mathrm{kg}^{-1}$ soil, potassium $\mathrm{K}_{2} \mathrm{O}-118$ to 124 $\mathrm{mg} \mathrm{kg}^{-1}$ soil.

During the 2010 - 2013 seasons were harvested seed yields from flax varieties and lines are presented on Fig. 2. The all studied years highest yield obtained from a variety 'Lirina' (average seed yield $2.54 \mathrm{t} \mathrm{ha}^{-1}$ with variations coefficient $\mathrm{V}=8 \%$ ). This variety by genetic composition is the most valuable, because unable to give a high yield at different temperatures and humidity. Only in the 2012 higher harvesting is carried out from varieties 'Flanders' (average seed yield $2.10 \mathrm{t} \mathrm{ha}^{-1}$, with variations coefficient $\mathrm{V}=15 \%$ ), 'Scorpion' (average seed yield $1.88 \mathrm{t} \mathrm{ha}^{-1}$, with variations coefficient $\mathrm{V}=16 \%$ ), 'German Serenade' (average seed yield $1.49 \mathrm{t} \mathrm{ha}^{-1}$, with variations coefficient $\mathrm{V}=24 \%$ ), 'Duches' (average seed yield $1.97 \mathrm{t} \mathrm{ha}^{-1}$, with variations coefficient $\mathrm{V}=11 \%$ ) and
‘Amon' (average seed yield $1.85 \mathrm{t} \mathrm{ha}^{-1}$, with variations coefficient $\mathrm{V}=17 \%$ ). High seed yield for these varieties explaining by high moisture content in vegetation period. The genetic resource permits the production of high yields under certain weather conditions.

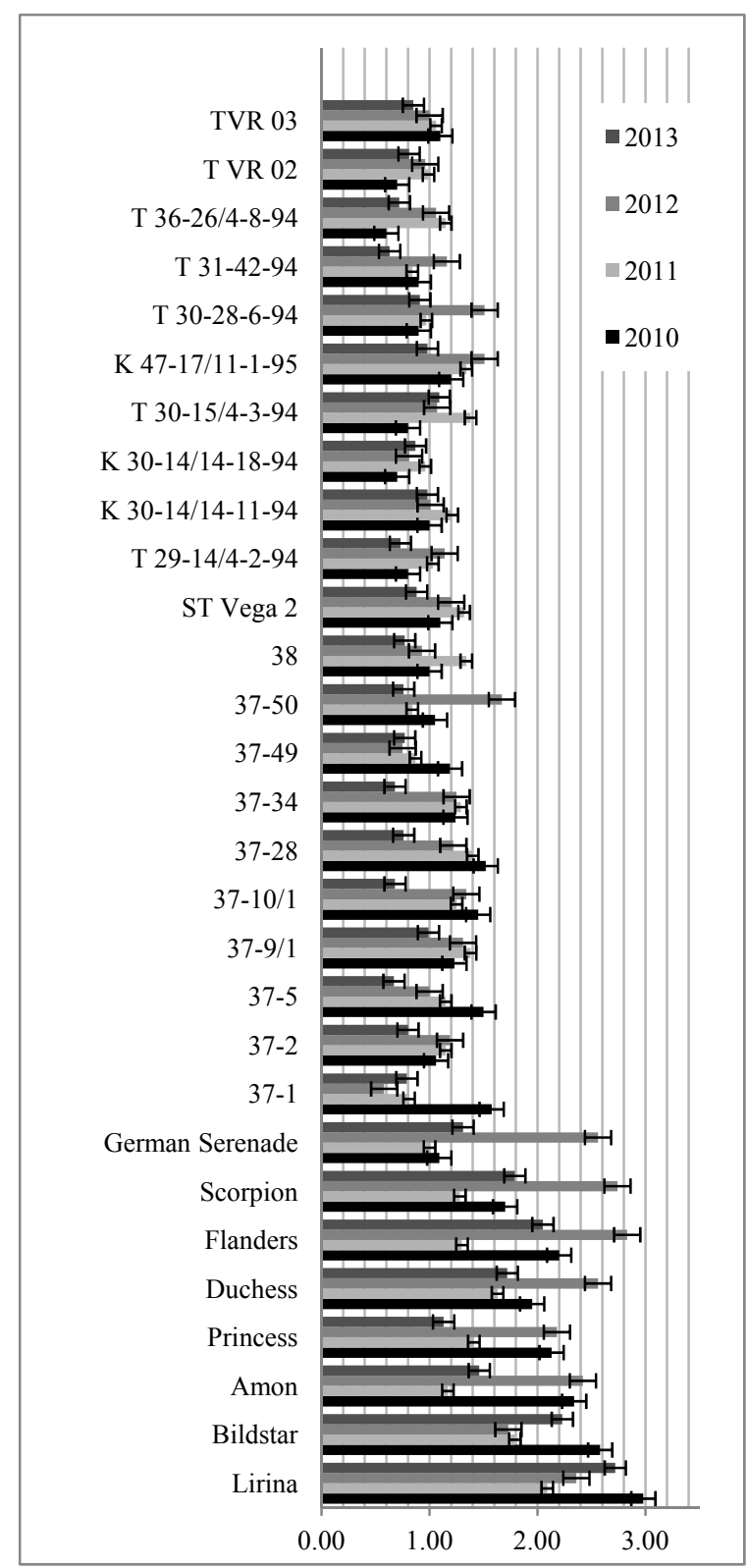

Fig.2. Seed yield $\left(\mathrm{t} \mathrm{ha}^{-1}\right)$ of flax varieties and lines 


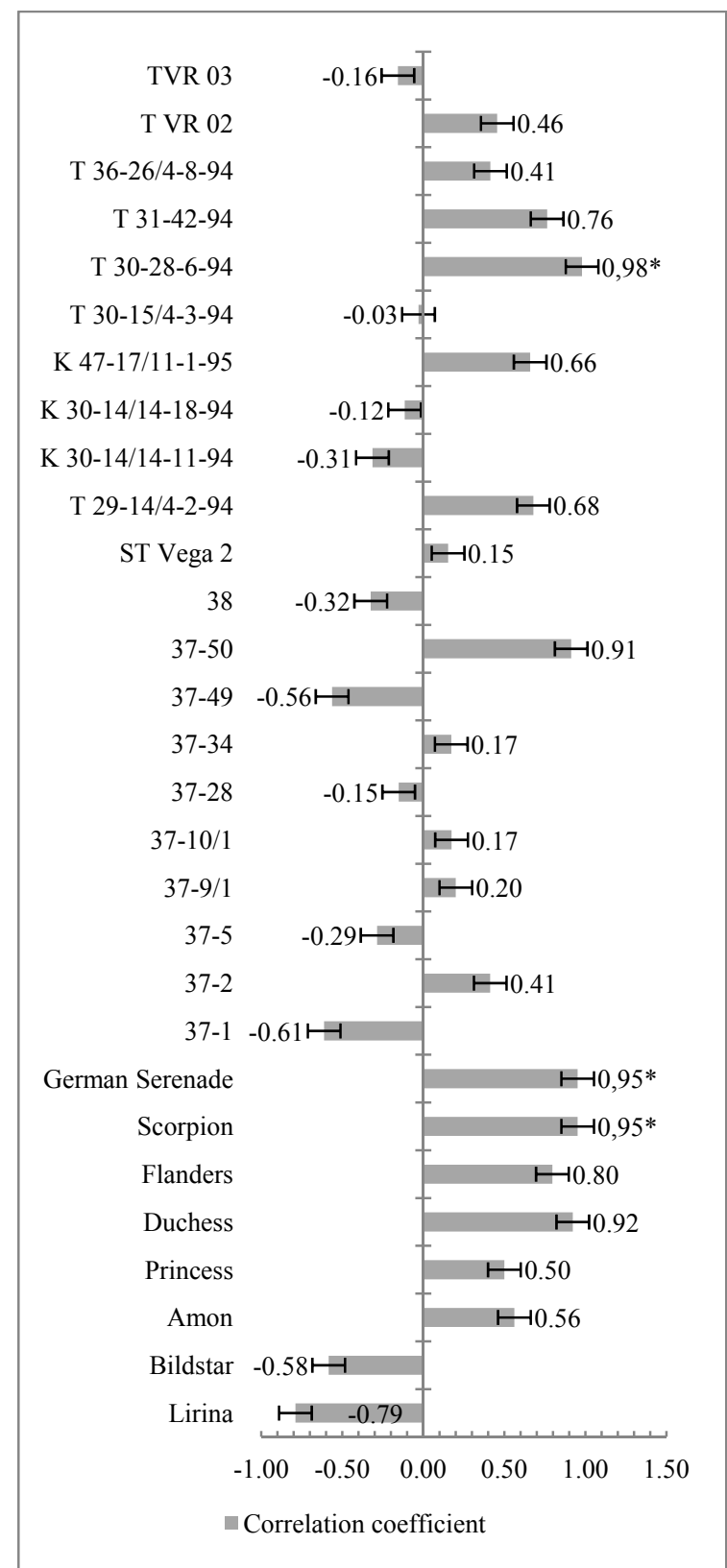

Fig.3. Correlation coefficient between seed yield and HTC in flax varieties and lines $(*-$ correlation significant at $\mathrm{p} \leq 0.05)$

Correlation coefficients are displayed between each flax varieties/lines of seed yield and HTC in Fig. 3. Positive and significant relationships were found 'T30-28-6-94' ( $\left.\mathrm{r}=+0.98^{*}\right), \quad$ 'German Serenade' $\left(\mathrm{r}=+0.95^{*}\right)$ and 'Scorpion' $(\mathrm{r}=+0.95 *)$. In this case, the yield formation significantly was influenced by environmental conditions. Major negative, but no significant coefficient was found 'Lirina' $(\mathrm{r}=-0.79)$.

Multiple correlation coefficients among the characters investigated in the experiments presented in Table1.

Positive and significant relationships were found between seed yield and 1000 seed weight $(\mathrm{r}=+0.59 * *)$, number of seed vessels per plant $\left(\mathrm{r}=+0.77^{* *}\right)$, number of seed per vessels $\left(\mathrm{r}=+0.40^{*}\right)$ and vegetation period $\left(\mathrm{r}=+0.85^{* *}\right)$. The effects are related to environmental condition and genotypic reason. [12], [27] - [34] working on flax also found similar results. The research shows these indicators as are important to obtaining high seed yield.

As it is seen from Table 1 positive and significant correlation was found between 1000 seed weight and number of seed-vessels per plant $(\mathrm{r}=+0.68 * *)$ and vegetation period $(\mathrm{r}=+0.53 * *)$.

TABLE 1

\begin{tabular}{llllll}
\hline $\begin{array}{l}\text { Investigated } \\
\text { characters }\end{array}$ & SY & OC & 1000SW & NSVP & NSV \\
\hline OC & $-0,03$ & & & & \\
1000SW & $0,59^{* *}$ & $-0,36$ & & & \\
NSVP & $0,77^{* *}$ & $-0,39 *$ & $0,68^{* *}$ & & \\
NSV & $0,40^{*}$ & $-0,28$ & 0,14 & $0,42^{*}$ & \\
VP & $0,85^{* *}$ & $-0,09$ & $0,53^{* *}$ & $0,73^{* *}$ & 0,26 \\
\hline
\end{tabular}

SY: Seed Yield, OC: Oil Content, 1000SW: 1000 Seed Weight, NSVP: Number of Seed Vessel per Plant, NSV: Number of Seed per Vessel, VP: Vegetation Period, * - correlation significant at $\mathrm{p} \leq 0.05, * *-$ correlation significant at $\mathrm{p} \leq 0.01$

\section{CORRELATION COEFFICIENT OF SEED YIELD AND COMPONENTS IN FLAX}

As also number seed vessels per plant positive and significant correlated between number of seed per $\operatorname{vessel}(\mathrm{r}=+0.42 *)$ and vegetation period $(\mathrm{r}=+0.73 * *)$.

Negative and significant relationships were found between oil contents and number of seed vessel per plant $\left(\mathrm{r}=-0.39^{*}\right)$. In this case, results were showed that on the development of the oil content high influence have genotypes. Oil contents in seed of flax varieties and lines are showed in Fig. 4. Apart from the seed yield the high oil content derived from variety 'Amon' with average $53.03 \%$. All investigated years oil content ranged from 42.8 to $53.03 \%$.

The relative contribution of yield components to the yield varied largely depending upon the environment, which was supported by the previous work [34] - [36]. 


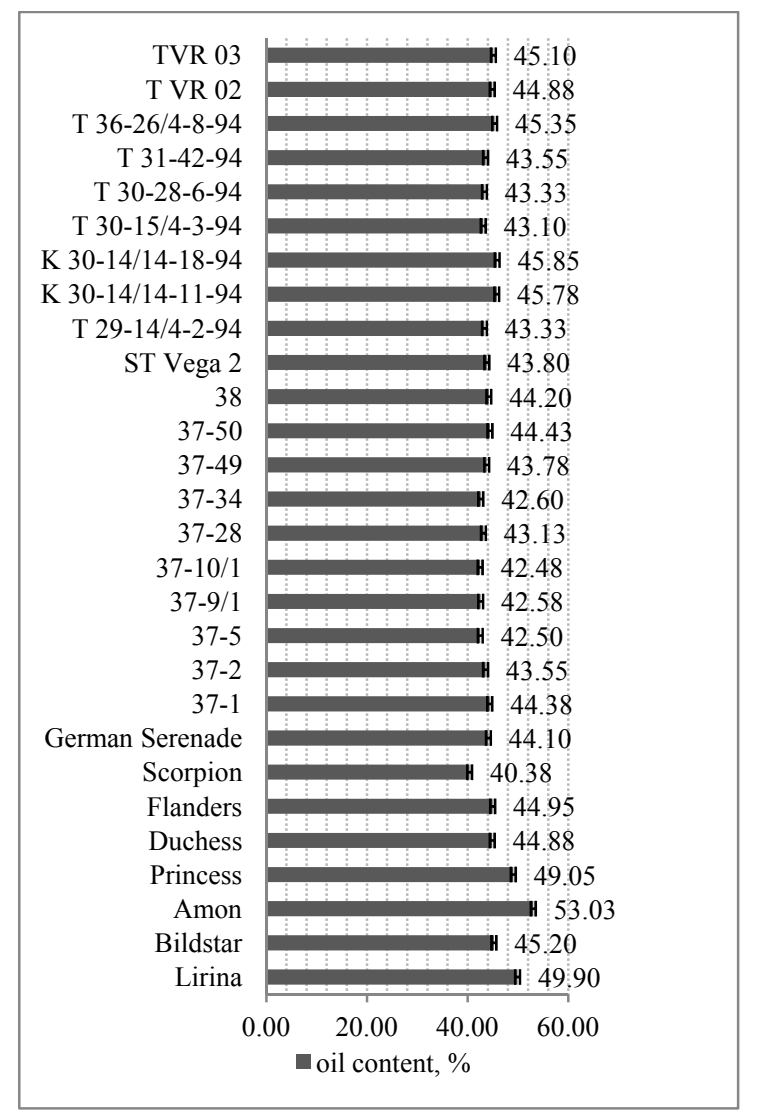

Fig.4. Oil content (\%) in seeds of flax varieties and lines

\section{$\mathrm{V}$ CONCLUSIONS}

The best stability in changeable environmental conditions and higher seed yield was showed variety 'Lirina' (average seed yield $2.54 \mathrm{t} \mathrm{ha}^{-1}$ with variations coefficient $\mathrm{V}=8 \%$ and $\mathrm{r}=-0.79$ ).

The study was proved that for the some varieties and lines rainfall and temperature averages significantly affect the vegetative and reproductive stages of development of flax. Positive and significant relationships were found ' $\mathrm{T} 30-28-6-94$ ' $(\mathrm{r}=+0.98 *)$, 'German Serenade' $\left(\mathrm{r}=+0.95^{*}\right)$ and 'Scorpion' ( $\mathrm{r}$ $\left.=+0.95^{*}\right)$. May recognized that these varieties at high humidity quantity during the season are directly or indirectly affected by positive yield increase.

They are of particular interest for the further collecting of genetic resources and show a wide spectrum of agronomic variability among the varieties investigated. The results obtained have shown that the agronomic parameters are very useful for the initial description.

\section{REFERENCES}

[1] Zohary, D., and M. Hopf. 2000. Domestication of plants in the Old World. 3rd ed. Oxford Univ. Press, Oxford, pp. 125-132.

[2] Muir, A., and N.Westcott. (2003) Flax, the genus Linum. Taylor and Francis, London.

[3] Singh, K.K., Mridula, D., Rehal, J. and Barnwal, P. (2011) Flaxseed: a potential source of food, feed and fiber. CRC Crit. Rev. Food Sci. Nutr. 51, 210-222.
[4] Toure, A. and Xu, X.M. (2010) Flaxseed lignans: source, biosynthesis, metabolism, antioxidant activity, bio-active components, and health benefits. Compr. Rev. Food Sci. Food Saf. 9, 261-269.

[5] Mohammadi AA, Saeidi G, Arzani A (2010) Genetic analysis of some agronomic traits in flax (Linum usitatissimum L.) Aust J Crop Sci 4: 343-352.

[6] Simmons, C.A., Turk, P., Beamer, S., Jaczynski, J., Semmens, K. and Matak, K.E. (2011) The effect of a flaxseed oilenhanced diet on the product quality of farmed brook trout (Salvelinus fontinalis) fillets. J. Food Sci. 76, S192-S197.

[7] Bilalis,D.J., Karkanis,A., Papastylianou,P., Patsiali, S., Athanasopoulou, M., Barla, G., Kakabouki, I. (2010) Response of organic linseed (Linum usitatissimum L.) to the combination of tillage systems, (minimum, conventional and no-tillage) and fertilization practices: Seed and oil yield production. AJCS 4(9):700-705

[8] Diederichsen A, Raney JP, Duguid SD (2006a) Variation of mucilage in flax seed and its relationship with other seed characters. Crop Sci 46:365-371

[9] Guilloux K, Gaillard I, Courtois J, Courtois B, Petit E (2009) Production of arabinoxylan-oligosaccharides from flaxseed (Linum usitatissimum). J Agric Food Chem 57:11308-11313

[10] Avachat AM, Dash RR, Shrotriya SN (2011) Recent investigations of plant based natural gums, mucilages and resnis in novel drug delivery systems. Ind J Pharm Edu Res 45:86-99

[11] Bhatty RS (1993) Further compositional analyses of flax: mucilage, trypsin inhibitors and hydrocyanic acid. J Am Oil Chem Soc 70:899-904

[12] Osman, C.M., Alilla, G., Mehmet, K. and Ufuk, D. (2006) Determination of Correlation and Path Analysis among Yield Components and Seed Yield in Oil Flax Varieties (Linum usitatissimum L.). Journal of Biological Sciences 6 (4): 738743.

[13] Casa, R., Russell, G., Lo Cascio, B. and Rossini, F. (1999) Environmental effects on linseeds yield and growth of flex at different seed rates. Eur. J. Agron. 11: 267-277.

[14] Cross, R.H., McKay, S.A.B., McHughen, A.G. and BonhamSmith, P.C. (2003) Heat stress effects on reproduction and seed set in Linum usitatissimum L. (flax). Plant Cell Environ. 26: 1013-1020.

[15] Tadesse, T., Singh, H. and Weyessa, B. 2009. Correllation and path coefficient analysis among seed yield traits and oil content in Ethiopian linseed germplasm. Int. J. Sustain. Crop Prod. 4: 8-16.

[16] Ford, J.H. (1964) The influence of time of flowering on seed development of flax. Crop Sci. 4: 52-54.

[17] Soto-Cerda, B. J., Duguid, S., Booker, H., Rowland, G., Diederichsen, A. and Cloutler, S. (2014a) Genomic regions underlying agronomic traits in linseed (Linums usitatissimum L.) as revealed by association mapping. J. Integr. Plant Biol. 56: 75-87.

[18] Rashal, I., Stramkale, V., (1998) Conservation and use of the Latvian flax genetic resources. Proceedings of the Symposium "Bast Fibrous Plants Today and Tomorrow. Breeding, Molecular Biology and Biotechnology beyond 21th century", 28-30 September 1998, St. Petersburg, Russia. Natural Fibres, iss. 2, , p. $56-58$.

[19] Grauda, D., Stramkale,V., Rašals, I. (2004) Evaluation of Latvian flax varieties and hybrids. Proceedings in Agronomy, No. 6, p. 159-165.

[20] Liu W, Kim MY, Van K, Lee YH, Li H, Liu X, Lee SH (2011) QTL identification of yield related traits and their association with flowering and maturity in soybean. J Crop Sci Biotech 14: $65-70$

[21] Shi J, Li R, Qiu D, Jiang C, Long Y, Morgan C, Bancroft I, Zhao J, Meng J (2009) Unraveling the complex trait of crop yield with quantitative trait loci mapping in Brassica napus. Genetics 182: 851-861

[22] Parry MAJ, Hawkesford MJ (2012) An integrated approach to crop genetic improvement. J Integr Plant Biol 54: 250-259 
[23] Cadic E, Coque M, Vear F, Grezes Besset B, Pauquet J, Piquemal J, Lippi Y, Blanchard P, Romestant M, Pouilly N, Rengel D, Gouzy J, Langlade N, Mangin B, Vincourt P (2013) Combined linkage and association mapping of flowering time in Sunflower (Helianthus annuus L.). Theor Appl Genet 126: $1337-1356$

[24] Stramkale, V., (2013) Latvijas atjaunojamo izejvielu - linu un kaņepāju produktu īpašǐbu pētījumi, to pielietošana inovatīvu tehnologiju un jaunu funkcionālu materiālu izstrādei. Pārskats par 2010.,2011.,2012., 2013. Gadu SIA "Latgales lauksiamniecības zinātnes centrs" I. un II. Daḷa Vị̣āni (unpublished)

[25] Selyaninov, GL. (1928) About the agricultural evaluation of the climate. TrudyGGO, 20:177-185. (in Russian)

[26] Шпаар Д., Гинапп Х., Щербаков В. и др. (1999) Яровые масличные культуры / Под общ. ред. В.А. Щербакова. Мн.:«ФУАинформ», - 288 с.

[27] Vijaukumar,S. and M.J.V.Rao (1975) Studies on the quantitative variability in linseed analysis of yield components. Field Crop Abs., $28: 644$

[28] Vijaukumar,S., M.J.V.Rao and S.W.Mersinkal, (1976) Study of variability and charect association analysis of linseed (Linums usitatissimum L.). Field Crop Abs., 29 : 527

[29] Basu, N.C. and S. Bose (1976) Preliminary studies on some botanical, anatomical and agronomical aspect of flax (Linums usitatissimum L.) Plant Breed. Abs., 46:618.
[30] Chandra, S., (1977) Use of index selection method in improvement of yield linseed (Linum usitatissimum L) Plant Breed. Abs., 47: 994

[31] Shehata, A.H. and V.E. Costock, 1977. Associations among economic attributes of flax (Linums usitatissimum L.). Field Crops Abs., 30: 359

[32] Kaynak,M.A. (1998) Determination of correlation among characters with effects of different amount of seed on yield and yields components of oilseed flax. Harran University, J. Fac. Agric., 2: 55-64 (Turkish)

[33] Can, R.R.A., S. Yüce, F. Aykut and M.A. Furan, (2003) Relationship among some agronomic characteristics in flax. The 5th Field Crops Congress of Turkey. Proceeding of Plant Breeding Vol. I.University of Dicle, Faculty of Agroculture, Department of Field Crops, 13-17 October 2003, DiyarbakirTurkey (Turkish)

[34] Murali, K. Darapuneni, Gaylon D. Morgan, Amir M. H. Ibrahim \& Robert W. Duncan (2014) Association of Flax Seed Yield and Its Components in Southeast Texas Using Path Coefficient and Biplot Analyses, Journal of Crop Improvement, 28:1, 1-16

[35] Giunta, F., R. Motzo, and M. Deidda. (1993) Effect of yield on yield and yield components of durum wheat and triticale in a Mediterranean environment. Field Crop Res. 33:399-409.

[36] Tivoli, B., C. Beasse, E. Lemarchand, and E. Masson. 1996. Effect of ascochyta blight (Mycosphaerella pinodes) on yield components of single pea (Pisum sativum) plants under field conditions. Ann. Appl. Biol. 129:207-216. 